\title{
Cultural Dimensions, Ethical Sensitivity, and Corporate Governance
}

\author{
Alex W. H. Chan · Hoi Yan Cheung
}

Received: 12 November 2010/ Accepted: 8 December 2011/Published online: 24 December 2011

(C) The Author(s) 2011. This article is published with open access at Springerlink.com

\begin{abstract}
The economic globalization process has integrated different competitive markets and pushes firms in different countries to improve their managerial and operational efficiencies. Given the recent empirical evidence for the benefits to firms and stakeholders of good corporate governance $(\mathrm{CG})$ practice, it is expected that good CG practice would be a common strategy for firms in different countries to meet the increasingly intense competition; however, this is not the case. This study examines the differences in CG practices in firms across different countries using the concept of ethical sensitivity. Through the regression analysis of 271 firms in 12 countries and regions, it is found that Hofstede's cultural dimensions can explain the differences in CG practices. Furthermore, the results demonstrate the influence of culture on ethical sensitivity, which eventually determines the CG practices in different regions.
\end{abstract}

Keywords Ethical sensitivity - Corporate governance · Cultural dimensions $\cdot$ Emerging markets $\cdot$ Behavioral finance

Corporate governance (CG) is a term that describes how well corporate management works for shareholders. It has

\footnotetext{
A. W. H. Chan $(\bowtie)$

School of Economics and Finance, Faculty of Business and Economics, The University of Hong Kong, K.K. Leung Building, Pokfulam Road, Hong Kong e-mail: alexchan@econ.hku.hk

H. Y. Cheung

Department of Applied Social Studies, City University of Hong

Kong, Tat Chee Avenue, Kowloon, Hong Kong

e-mail: hycheun3@cityu.edu.hk
}

been extended to describe the relationship between the management and other stakeholders or corporate participants, including creditors, employees, customers, and society in general (OECD 2004). Good CG practice means that the corporate management has demonstrated its responsibility to protect the interests of shareholders and other stakeholders (e.g., lenders, customers, and employees), and promoted corporate fairness, transparency, and accountability to its stakeholders.

Recent empirical research has documented the advantages that accrue to firms and stakeholders from good CG practices. Credit Lyonnais Securities Asia (CLSA), a leading investment bank in the Asian markets, undertook a comprehensive survey of the CG of corporations to measure corporate performance in emerging markets. The CLSA (2001) report provided the details of this survey, conducted on 495 firms, and the results showed that CG had a significant influence on a corporation's performance. CLSA (2001) found that CG scores were positively related to financial performance. Corporations with high $\mathrm{CG}$ scores generally earned a higher return on equity. The survey results indicated that corporations with good CG were better able to manage and control expenses and were more profitable. CLSA also found that corporations with high CG scores performed better on the stock market and provided higher than average returns to stockholders than corporations with low CG scores. The findings of Gompers et al. (2003) were similar to those of the CLSA report. They found a close correlation between a corporation's stock performance and its CG score. They constructed a CG index to measure the level of shareholder rights for 1,500 large corporations. The results showed that a high return of $8.5 \%$ per annum could be earned simply by investing in companies with a high CG index and selling the shares of those with a low CG index. Gompers et al. 
(2003) also found that corporations with stronger shareholder rights had, in general, higher firm values, higher profitability, higher sales growth, and lower capital expenditures.

The economic globalization process has integrated different competitive markets from around the world. Firms in different countries have been pushed to improve their managerial and operational efficiencies under the increasingly competitive environment. Given the recent empirical evidence for the benefits that accrue to firms and stakeholders from good CG practice, it would be expected that good CG practice should be a common strategy for firms in different countries; however, this is not the case. There are firms that do not follow good CG practice. Klapper and Love (2004) investigated the effect of the legal system on CG practice. They used the data from the CLSA (2001) survey to study the CG of corporations in countries with different legal systems. They found that in countries with strong legal systems, firms usually had high CG scores. They also investigated the effect of CG on corporate performance and found that on the average, firms with better CG had a better operating performance and a higher market valuation; this relationship was even more significant for corporations in countries with weak legal environments.

To investigate the determinants for CG development, Doidge et al. (2007) developed a theoretical model based on the implementation cost of CG practice. They found that the characteristics of countries could explain the variation in CG practices. Their theoretical model predicted that firms would have very little incentive to improve CG if the economic development of the country was below a threshold level. Black et al. (2006b) also conducted an empirical investigation into the determinants of CG development, using a Korean dataset. They found that some firm-specific factors (e.g., firm size, firm risk, and profitability) could significantly explain the Korean corporate governance index (KCGI) of different Korean firms.

\section{Theoretical Foundation}

Relationships Among CG, Ethical Sensitivity, and Cultural Dimensions

Although CG practice and ethical sensitivity are highly related, they are not exactly the same. A major reason for the management to voluntarily maintain good CG practice (such as to provide accountability and transparency of internal operation to outside investors) is to lower the future external financing cost. Doidge et al. (2007) provided a theoretical model for the firm's choice of CG practice by analyzing the costs and benefits of implementing measures to improve the CG structure and operational transparency.
Firms with a better CG structure can earn the trust of external investors; hence, they can borrow money at a lower borrowing cost and also issue new shares at a higher offer price to investors. In other words, the major benefit of good CG practice is to have a lower external funding cost. In view of this economic benefit, an internal corporate manager with low ethical sensitivity may have to adopt good CG practice to attract funding from external investors at a lower cost. Hence, good CG practice is not exactly the same as high ethical sensitivity. However, in general, when holding other variables constant, a corporate management team with higher ethical sensitivity will implement better CG practice. The underlying reasons are provided in the following paragraphs.

CG describes how well the corporate management works for the shareholders and other stakeholders. CG has many ethical implications (Thomas 2004). According to Rossouw (2005), "the way in which a company treats its stakeholders reflects its ethical standards. It is therefore to be expected that companies for whom ethics is a priority will be sensitive to its stakeholders. This moral sensitivity will be reflected in the identification of stakeholders as well as in the manner in which they are being engaged by the company" (p. 99).

Bonn and Fisher (2005) developed an approach to integrate business ethical concerns into the CG structure of an organization. It is important to know that the existence of a code of ethical conduct is not sufficient to ensure the practice of ethical behavior throughout organizations. Furthermore, people should not view the code of ethics as guidelines to be followed simply to please their bosses and auditors. Instead, careful strategic planning is needed to communicate CG to everyone in an organization, so that they recognize the importance of the guidelines and practice good CG. For example, to ensure that employees practice good CG, there should be extensive and frequent discussions amongst people in the organizations, including the board of directors, senior managers, middle managers, and other employees. In addition to formal discussions of CG, informal discussions about CG can help identify potential gray areas and improve the quality of ethical thinking. Moreover, there should be development and training for staff so that CG is clearly understood by everyone in the organizations. Eventually, employees will be committed and dedicated to practicing good CG.

Implementation of a CG structure may sometimes create conflicts between the directors and shareholders. One of the possible conflicts is that some directors may be hesitant to punish ineffective managers because of their close connection. This hesitation is certainly not a good CG practice, because shareholders' interest will be badly affected if ineffective managers continue to serve in the firms. However, Felo (2001) showed that when firms offer ethics 
programs to employees, the firms are less likely to have conflicts within the CG structures. This is because ethics programs can help directors and employees to recognize ethical conflicts and find ways to resolve them within the CG structure, so that they can smoothly implement good CG practice. In other words, the better people recognize ethical issues, the fewer ethical conflicts they have and the better their CG practices.

Overall, good CG practice is not easy to maintain because it requires well-designed ethics policies, ethical leadership, and incorporating ethics into the organizational processes and strategies. It is important to have an ethical culture at all levels of the organization (Webley and Werner 2008). Hence, based on the above studies, for organizations to be considered as practicing good CG, every employee in the organization must be aware of and recognize the importance of complying with the ethical code or guidelines. Interestingly, ethical sensitivity is defined by Hebert et al. (1990) as "the ability to recognize ethical issues" (p. 141). Shaub (1989) describes ethical sensitivity as the "ability to recognize that a situation has ethical content when it is encountered" (p. 7). In this study, we considered employees' ethical sensitivity as one of the major elements in developing good CG practice.

Shaub et al. (1993) explained that an important factor in people's decision to perform ethical actions is their recognition of their role as moral agent. Furthermore, they must have ethical sensitivity to recognize such a role and to think about the consequences they can bring by acting ethically. Orlitzky and Swanson (2010) considered executives as having ethical sensitivity when they are able to lead their firms toward good corporate citizenship and provide benefits to society, such as financial returns to shareholders, fair employment standards for workers, etc. Executives with ethical sensitivity must have both organizational and societal responsibilities. The above-mentioned forms of behavior are, in fact, some of the many good practices of CG. Corporate management must have ethical sensitivity to practice CG in a firm. Even if the ethical criteria or good practices of CG are explicit and written down, if individuals, especially those in the corporate management team, are not aware of or ignore those ethical criteria, then they are useless. Thus, the ethical sensitivity of individuals plays a major role in whether good CG practices are followed.

In terms of the relationship between cultural dimensions and ethical sensitivity, Mintz (2006) suggested that the cultural environment has a greater impact on people's ethical sensitivity than the enforcement of rules of conduct. Fernando and Chowdhury (2010) also noted that an individual's cultural background has a great impact on ethical sensitivity. Research on ethical sensitivity in the business world is growing. Many studies have investigated the relationship between culture and ethical sensitivity, and some have examined it from a macro-perspective. For example, Blodgett et al. (2001) found that cultural dimensions had significant effects on ethical sensitivity. This study compared the ethical sensitivity of people from Taiwan and the United States towards the interests of various stakeholders, in marketing situations. Stakeholders included employers, customers, stockholders, creditors, suppliers, colleagues, competitors, and other communities or groups that might be affected by decisions involving ethical issues. The results showed that ethical sensitivity was influenced by culture.

Some studies have investigated the relationships between Hofstede's cultural dimensions and ethical issues. In fact, Hofstede's cultural dimensions can be described in terms of pairs of dimensions (Rawwas 2001). For example, people from a culture with a small power distance index (PDI) and weak uncertainty avoidance are known as functionalists. People living in cultures with a high PDI and strong uncertainty avoidance are called deferents. Survivors are people from cultures with a weak PDI and strong uncertainty avoidance, while enthusiasts are from cultures with a strong PDI and weak uncertainty avoidance. Rawwas (2001) found that these four types of people held different perceptions on the appropriateness of behavior in the marketplace. For example, deferents, who are characterized as being very obedient to their own bosses' rules and long-range plans to avoid anxieties about the future, were found to have stringent ethical beliefs.

In a study of 425 managers from 10 nations and 4 continents, Jackson (2001) found that the ethical attitudes of managers were related to their national groups. The study examined whether managers from different countries would attach high or low ethical importance to their relations with external stakeholders, such as gift giving and receiving. The results showed that managers from individualistic and low uncertainty avoidance countries gave higher ethical importance to relations with external stakeholders, whereas managers from individualistic and high uncertainty avoidance countries gave lower ethical importance to the same issue. In terms of collectivism, managers from collectivistic and high uncertainty avoidance cultures placed high ethical importance on issues involving relations with external stakeholders. On the other hand, managers from collectivistic and low uncertainty avoidance countries placed low ethical importance on this issue.

Hwang et al.'s (2003) study suggested that people from different cultures would handle business situations differently, and Husted and Allen (2008) studied the business ethical decision-making process by comparing individualistic and collectivistic countries. Generally speaking, different cultures (e.g., individualistic and collectivist) affect 
people's "perception of ethical dilemmas, moral reasoning, and the behavior of individuals in organizations" (Husted and Allen, p. 301).

Other studies have examined the relationship between culture and ethical sensitivity from a micro-perspective. For example, Chen et al. (1997) studied the impact of corporate culture on ethical sensitivity and behavior. Patterson (2001) found that industry environment, organizational environment, and personal experiences all significantly affected the ethical sensitivity of auditors.

Based on the relationship between cultural dimensions and ethical sensitivity, and the relationship between ethical sensitivity and CG, this study investigated the variation in CG practices across cultures, using the cultural dimensions developed by Hofstede and Hofstede (2005): power distance index (PDI), individualism (IDV), masculinity (MAS), uncertainty avoidance index (UAI), and long-term orientation. This article omitted long-term orientation as an independent variable, because the data collected by Hofstede (2001) for this variable were not as extensive as those collected for the other four cultural dimensions (Hofstede 2001).

The hypotheses below were developed according to the levels of ethical sensitivity of different cultures found in previous studies (Armstrong 1996; Blodgett et al. 2001; Ho and Lin 2008; Schepers 2006).

\section{Hofstede's Cultural Dimensions-PDI, IDV, MAS,} and UAI

The cultural dimensions developed by Hofstede (2001), are widely used in different areas of research for understanding culture. Culture is defined by Hofstede (2001) as "the collective programming of the mind that distinguishes the members of one group or category of people from another" (p. 9). Cultural traits of nations are difficult to change; for example, Chinese people have been guided by Confucianism since approximately 500 B.C., when Kong Fu Ze was teaching. This set of pragmatic rules is still affecting the behavior of Chinese people today, even those who have moved to other countries (Hofstede and Bond 1988). The five cultural dimensions developed by Hofstede included PDI, IDV, MAS, UAI, and long-term orientation.

Power is unequally distributed among the members of high PDI societies, and less powerful people are afraid of contradicting authorities. They must accept the fact that power and benefits are unequally distributed, and that power and benefits are controlled by a few powerful people (Hofstede 1984). People in low PDI societies have more control over their lives, and authorities in this culture are willing to listen and accept different opinions from others before making decisions, especially when those decisions have a great impact on society.
People from high IDV societies are independent; they focus on themselves and emphasize adherence to personal norms and goals. People in low IDV societies, on the other hand, emphasize the interdependence between themselves and their group or community. They feel obliged to follow social duties, expectations, roles, and other societal influences (Triandis 1995, 1996; Triandis et al. 1998).

Men and women are treated differently in high MAS societies, and people in these societies are ego-oriented (Hofstede 2001). People tend to be tough in such societies, and men are encouraged to be assertive and ambitious. They must be tougher than women, who should be tender and caring. Generally speaking, people in high MAS societies emphasize challenges, earnings, recognition, and advancement (Hofstede and Hofstede 2005).

People in high UAI societies have low tolerance for ambiguity, are relatively conservative, have a strong desire to obey the existing social system and management practice, and are afraid of foreign or external things. They are afraid of uncertainty. People in low UAI ranking countries are more willing to accept changes and take greater risks, because they feel that they have more control over their lives, the authorities, and even the world (Hofstede 1984).

Hofstede's cultural dimensions help in understanding culture differences, but they cannot describe the whole culture. Also, the reliability and validity of these cultural dimensions have been questioned by other researchers. Smith et al. (1996) stated that Hofstede's cultural dimensions had significant correlations with geographic, economic, and social indicators, and that the correlation between IDV and economic development was strong. Establishing correlations was a way of validating Hofstede's cultural dimensions. They also criticized the sample, as Hofstede collected data from respondents who all worked in the same corporate culture. Therefore, the respondents might not be representative of the broader national population. However, they concluded that the reliability and durability of these cultural dimensions could be seen by "the extent that similar patterns of findings emerge from different types of samples, different time periods, and measures from different domains of social behaviors" (Smith et al. 1996, p. 234).

Moreover, Hofstede's cultural dimensions were correlated with Chinese Culture Connection (CCC) factors and it was found that PDI and IDV were significantly and moderately correlated with the CCC variables of integration and moral discipline. A strong correlation was found between MAS and the human heartedness factor of CCC. Hofstede's cultural dimensions were also significantly correlated with Schwatz's value types. These correlations of cultural dimensions with other factors are convincing and are not coincidental as the data for the CCC factors and 
Schwatz's value types were collected from different cultures and with different types of samples.

\section{Hypothesis Development}

Blodgett et al. (2001) found that a lower PDI was related to an increase in ethical sensitivity in business transactions toward stakeholders, such as customers, competitors, and colleagues. Those who make important business decisions in high PDI cultures are usually powerful and wealthy, and consider their own interests to be more important than those of other stakeholders (Blodgett et al. 2001; Hofstede 2001). Such individuals believe that they are entitled to more privileges than ordinary people. However, as discussed above, good CG practices and ethical sensitivity are positively related, and CG generally protects the interests of every stakeholder, not just the powerful decision makers in corporations. Therefore, individuals in low PDI cultures have higher ethical sensitivity, because they believe that everyone should be treated fairly and that benefits should be equally distributed. Individuals in low PDI cultures act on their beliefs and perform more ethical behaviors (Hofstede and Hofstede 2005). Based on the negative relationship between low PDI and ethical sensitivity and the positive relationship between ethical sensitivity and CG, the following hypothesis is developed.

Hypothesis 1 The quality of CG is higher in low PDI cultures.

Simga-Mugan et al. (2005) showed that when compared with managers from Turkey, a country which scored low in Hofstede's IDV dimension, managers from the United States were found to have higher ethical sensitivity, due to their country's high IDV score. In fact, the positive relationship between ethical sensitivity and IDV can be seen in different studies (Cohen et al. 1996; Smith and Hume 2005). Franke and Nadler (2008) demonstrated that people in low IDV cultures would favor in-groups at the expense of out-groups, leading to ethical insensitivity especially when the unethical acts benefited the in-groups. In contrast, the ethical attitudes of people from high IDV cultures reflect "an assertive self-orientation that limits conformity" (Franke and Nadler 2008, p. 256). Moreover, Hofstede (2001) described people from high IDV cultures as placing high emphasis on individual rights and fair treatment, and thus they are highly aware of the unethical behavior of others and themselves. When the relationships between IDV and ethical sensitivity and between ethical sensitivity and CG are positive, the following hypothesis is developed.
Hypothesis 2 The quality of CG is higher in high IDV cultures.

Blodgett et al. (2001) found that MAS and ethical sensitivity were negatively related. MAS societies are characterized as money oriented, materialistic, aggressive, ambitious, competitive, and greedy, and people in high MAS cultures have less concerned for the interests of other people. This makes corporate management less concerned with the interests and benefits of their customers, competitors, and colleagues in the firms (Blodgett et al. 2001; Hofstede 2001). Vitell and Festervand (1987) found that the characteristics of people in high MAS cultures were the greatest contributors to unethical practices and ethical insensitivity, especially in business, because people sought financial gains. Lending and Slaughter (1999) also found that these people were less sensitive to organizational values. Overall, people who have low ethical sensitivity and disregard organizational values will have difficulty empathizing with other people and creating a fair business environment. Based on the ethical insensitivity of people in MAS cultures and the positive relationship between ethical sensitivity and CG, the following hypothesis is developed.

Hypothesis 3 The quality of CG is higher in low MAS cultures.

A number of studies have investigated the relationship between UAI culture and ethical sensitivity. High UAI culture is more compatible with formal rules and regulations. People with high UAI are more intolerant of any deviation from formal rules, regulations, and organizational norms (see Vitell et al. 1993; Blodgett et al. 2001; Weaver 2001). Vitell et al. (1993, p. 757) stated the proposition that " $[\mathrm{b}]$ usiness practitioners in countries that are high in uncertainty avoidance (i.e., Japan) will be more likely to consider formal professional, industry and organizational codes of ethics".

In contrast, when there is no formal rule or regulation to govern a business decision, it is less likely that a high UAI manager will recognize the ethical issue in a business decision. Vitell et al. (1993, p. 757) further stated the proposition that " $[\mathrm{b}]$ usiness practitioners in countries that are high in uncertainty avoidance (i.e. Japan) will be less likely to perceive ethical problems". The absence of formal laws and regulations for certain business decisions generates an ambiguous working environment, which provides more flexibility but also uncertainty to the management, and in turn makes the ethics management in high UAI culture more problematic. Weaver's (2001) study also noted that people in high UAI societies would have problems with ethics management conducted through anonymous reporting systems and informal cues, as such ethics rules would be perceived as ambiguous or unknown in their 
working environments. Following similar arguments, $\mathrm{Hu}$ sted (2000) stated that in the absence of formal rules and laws, anxiety over ambiguous and uncertain situations would make high UAI managers less likely to recognize their decision as an ethical issue, and hypothesized a higher rate of software piracy in higher UAI cultures.

In general, CG practice is not formally stated as laws or regulations in countries, except for a few examples of investor protection laws, such as laws against insider trading. Standards for good CG practice are usually guidelines and recommendations. They are neither formal legal regulations nor binding agreements between the internal management and external stakeholders. No country formally stipulates or legally enforces that corporate management must do their best for shareholders and other stakeholders. The standard of good CG practice is basically a set of informal guidelines. This leads to a certain degree of ambiguity over how to manage the firm, and generates uncertainty in the management team. Following the above arguments, the absence of formal rules or regulations governing a business decision will make a high UAI manager less likely to recognize the ethical issue in a business decision. From the perspective of internal management, reluctance to make the internal operation more transparent and to provide better accountability to outside stakeholders can greatly reduce the ambiguity of the management environment and the uncertainty of future outcomes. Hence, the management in high UAI culture is less likely to voluntarily practice good CG to avoid the uncertainty of outcomes. Based on the above studies, the following hypothesis is developed.

Hypothesis 4 The quality of CG is higher in low UAI cultures.

\section{Method}

\section{CG Measure}

The CG score data were obtained from a comprehensive survey carried out by CLSA, a leading investment bank in the Asian markets. The results of this survey are presented in a detailed 224-page report (CLSA 2001). Many researchers have successfully used the CLSA survey dataset to investigate different aspects of the impact of CG. For example, using these data, Klapper and Love (2004) investigated the relationship between CG development and the legal systems among different emerging markets. Durnev and Kim (2005) examined why some companies could develop better CG practices than those required by law. They predicted that companies with greater growth opportunities, greater needs for external financing, and more concentrated cash flow would have higher quality CG practices and would also disclose more information to the public. The CLSA data provided empirical evidence to support these predictions. Khanna et al. (2006) examined the relationship between globalization and similarities in CG through a cross-country analysis using CLSA data.

CLSA measured the CG practices of corporations in emerging markets over a 6-week period ending in March 2001. Emerging markets are newly developed or developing financial markets, which usually have a short operating history, smaller market capitalization, and lower trading volumes. As they are still in the process of development, their rules and regulations and CG structure are not completely mature. The survey covered 495 listed companies from 25 emerging markets and 18 industrial sectors. The questionnaires were completed by CLSA's financial analysts in each country of the companies covered. Their answers were based on each company's publications and on interviews with management and they rated the companies on 57 issues. The issues were grouped into seven CG factors: discipline, transparency, independence, accountability, responsibility, fairness, and social awareness. For each company, each CG factor was given a different percentage of importance to generate a weighted CG score (CLSA 2001). Table 1 provides the detailed information about the seven CG factors.

\section{Macroeconomic Factors}

The economic development and wealth level of a country are expected to be related to its level of CG development. The theoretical model from Doidge et al. (2007) predicts that economic development is an important determinant for CG development. Nicolò et al. (2008) investigated the real impact of $\mathrm{CG}$ on the growth and productivity of the economy. They found a positive relationship between the impact of improvements in CG quality and real economic activity. To take into account these macroeconomic factors, this study used the following control variables to indicate the differences in economic development among the investigated countries.

\section{$\log (G D P$ Per Capita $)$}

A country's wealth level can affect its CG development. This study used the natural logarithm of gross domestic product (GDP) per capita (in US\$) as the control variable for the wealth of a country. This study used the logarithm of GDP per capita (in US\$) in 2000 as a measure of the wealth level of each country for analysis. The GDP per capita (in US\$) in 2000 data were obtained from The World Competitiveness Yearbook 2001 (IMD 2001); however, the yearbook did not include the data for 
Table 1 Criteria of Individual CG Factors in CG Survey of Credit Lyonnais Securities Asia (CLSA)

I. Discipline (15\%)

a. Explicit public statement placing priority on $\mathrm{CG}$

b. Management incentivised towards a higher share price

c. Sticking to clearly defined core businesses

d. Having an appropriate estimate of cost of equity

e. Having an appropriate estimate of cost of capital

f. Conservatism in issuance of equity or dilutive instruments

g. Ensuring debt is manageable, used only for projects with adequate returns

h. Returning excess cash to shareholders

i. Discussion in Annual Report on CG

II. Transparency (15\%)

a. Disclosure of financial targets, e.g., 3- and 5-year ROA/ROE

b. Timely release of Annual Report

c. Timely release of semi-annual financial announcements

d. Timely release of quarterly results

e. Prompt disclosure of results with no leakage ahead of announcement

f. Clear and informative results disclosure

g. Accounts presented according to IGAAP

h. Prompt disclosure of market-sensitive information

i. Accessibility of investors to senior management

j. Website where announcements update promptly

III. Independence (15\%)

a. Board and senior management treatment of shareholders

b. Chairman who is independent from management

c. Executive management committee comprised differently from the board

d. Audit committee chaired by independent director

e. Remuneration committee chaired by independent director

f. Nominating committee chaired by independent director

g. External auditors unrelated to the company

h. No representatives of banks or other large creditors on the board

IV. Accountability (15\%)

a. Board plays a supervisory rather than executive role

b. Non-executive directors demonstrably independent

c. Independent, non-executive directors at least half of the board

d. Foreign nationals presence on the board

e. Full board meetings at least every quarter

f. Board members able to exercise effective scrutiny

g. Audit committee that nominates and reviews work of external auditors

h. Audit committee that supervises internal audit and accounting procedures

V. Responsibility (15\%)

a. Acting effectively against individuals who have transgressed

b. Record on taking measures in cases of mismanagement

c. Measures to protect minority interests

d. Mechanisms to allow punishment of executive/management committee
Table 1 continued

e. Share trade by board members fair and fully transparent

f. Board small enough to be efficient and effective

VI. Fairness (15\%)

a. Majority shareholders treatment of minority shareholders

b. All equity holders having right to call general meetings

c. Voting methods easily accessible (e.g., through proxy voting)

d. Quality of information provided for general meetings

e. Guiding market expectations on fundamentals

f. Issuance of ADRs or placement of shares fair to all shareholders

g. Controlling shareholder group owning less than $40 \%$ of company

h. Priority given to investor relations

i. Total board remuneration rising no faster than net profits

VII. Social awareness (10\%)

a. Explicit policy emphasizing strict ethical behavior

b. Not employing the under-aged

c. Explicit equal employment policy

d. Adherence to specified industry guidelines on sourcing of materials

e. Explicit policy on environmental responsibility

f. Abstaining from countries where leaders lack legitimacy

The information is obtained from pages 9-10 of "Saints and Sinners: Who's got religion", Credit Lyonnais Securities Asia Research Report, April 2001

Pakistan. Instead, the GDP per capita for Pakistan (in US\$) in 2000 was obtained from the National Accounts Statistics database from the United Nations (source: http://unstats. un.org/unsd/snaama/selbasicFast.asp).

\section{GDP Growth Rate}

We controlled for the impact of macroeconomic conditions on the development of CG practice by taking the average annual growth rate of GDP as a control variable in our analysis. The average annual GDP growth rates of different countries were collected between 1990 and 2000 from the World Development Indicator (World Bank 2006, pp. 195-197). As the data for Taiwan's GDP growth rate was not available from this source, this study collected Taiwan's historical GDP growth rate from the official website of the Department of Investment Services, Ministry of Economic Affairs, Taiwan (source: http:// investintaiwan.nat.gov.tw/en/env/stats/gdp_growth.html).

\section{Legal-Origin Factor}

Company law and commercial code are basically developed from two legal traditions: the common-law tradition and the civil-law tradition. La Porta et al. (1998) found that in general, countries under common-law systems provided 
stronger legal protection for investors than countries under civil-law systems. Hence, it is expected that countries under common-law systems will have better CG practices than countries under civil-law systems. To control for this legal environment effect, we used the following control variable for the legal system.

\section{Common-Law Dummy}

This common-law dummy variable was set to be ' 1 ' if the company law or the commercial code of the country originated from a common-law system, and ' 0 ' if it originated from a civil-law system. Our sample companies came from only twelve countries/regions, including seven countries with English common-law origins and five countries with civil-law origins. Due to the small number of countries of civil-law origin in our sample, we did not make any further classification into French, German, or Scandinavian civil law.

\section{Firm-Specific Financial Factors}

As Black et al. (2006b) empirically found that some firmspecific factors (including firm size, firm risk, and profitability) significantly explained CG for Korean firms, we also considered the following firm-specific financial factors as control variables in our analysis of the relationship between cultural dimensions and CG scores.

\section{Firm Size}

Firm size is a proxy for the information availability of a firm, because there are more analyst reports available for large firms. Most financial analysts concentrate on analyzing large companies in the market, so large firms become more transparent and are better monitored than small firms. Hence, it is expected that larger firms will have better CG. The market value of a firm is defined as the number of outstanding shares multiplied by the stock market price. The market value (in US\$ million) at the end of 2000 for each firm was collected from the database of Thomas Reuters Datastream to measure the firm size of each observation. This study took the natural logarithm of the market value of the firm, $\log$ (Market Value), as a control variable for this firm size effect.

\section{Market-to-Book Ratio}

A market value ratio of a firm measures the market price of its stock relative to the intrinsic value of the firm. A great deal of empirical research has been conducted to examine the relationship between $\mathrm{CG}$ and the market value ratios. For example, Black et al. (2006a) found significant positive relationships between the CG indexes of 515 Korean companies and their market value ratios (Tobin's $q$, market-to-book, and market-to-sales). Similarly, Garay and González (2008) found significant positive relationships between the CG indexes of 46 Venezuelan firms and their market value ratios (Tobin's $q$ and market-to-book). In this study, the market-to-book ratio at the end of 2000 was collected for each firm from the database of Thomas Reuters Datastream to measure the ratio between the market price per share and the accounting book value per share.

\section{Dividend Yield}

The agency problem (Jensen and Meckling 1976) is the conflict of interest between corporate managers (insiders) and shareholders (outsiders); that is, corporate managers may not maximize the value of the firm for the benefit of the shareholders. One example of the agency problem is the free cash flow problem (Jensen 1986), in which corporate managers with excess cash holdings choose to invest that cash in poorly performing projects rather than to return the profit to shareholders through cash dividend distribution. Agency theory (Rozeff 1982; Easterbrook 1984) holds that the dividend policy can be used to reduce management's agency cost. As the dividend policy can align the interests of managers with those of shareholders, it is predicted that the dividend yield would be related to CG, and therefore this study used dividend yield as a control variable. This yield is defined as the annual cash dividend per share over the stock market price. We collected the dividend yield data at the end of 2000 for each firm from the Thomas Reuters Datastream database.

We attempted to use as many observations as possible from CLSA's CG report for our analysis; however, some observations were excluded. As the CG report of CLSA provided only abbreviated company names, we excluded those observations with ambiguous company names. After merging different datasets, we excluded those observations with any missing data for the macroeconomic variables, legal-origin variables, firm-specific financial variables, and cultural dimension variables that were required for our analysis. Furthermore, to ensure that this study had sufficient samples from each country under investigation, only those countries with at least 10 valid firm observations were considered.

After combining the CG survey data of CLSA with the datasets of macroeconomic variables, legal-origin variables, firm-specific financial variables, and Hofstede's cultural dimensions, there were 271 complete observations across the following 12 countries and regions (the number of observations for each region are stated in parentheses): Hong Kong (29), India (47), Indonesia (17), Malaysia (34), 
Table 2 Means, standard deviations, correlations for dependent and independent variables

\begin{tabular}{|c|c|c|c|c|c|c|c|c|c|c|c|c|c|}
\hline \multirow[t]{2}{*}{ Variables } & \multirow[t]{2}{*}{ Mean } & \multirow[t]{2}{*}{ SD } & \multicolumn{11}{|c|}{ Correlations } \\
\hline & & & (a) & (b) & (c) & (d) & (e) & (f) & (g) & (h) & (i) & (j) & (k) \\
\hline (a) CG score & 55.21 & 14.38 & - & & & & & & & & & & \\
\hline $\begin{array}{l}\text { (b) } \log (\mathrm{GDP} \\
\text { per capita) }\end{array}$ & 8.12 & 1.49 & $0.27 * *$ & - & & & & & & & & & \\
\hline $\begin{array}{l}\text { (c) GDP } \\
\text { growth rate }\end{array}$ & 5.31 & 1.62 & $0.15^{*}$ & $0.26 * *$ & - & & & & & & & & \\
\hline $\begin{array}{l}\text { (d) Common- } \\
\text { law dummy }\end{array}$ & 0.68 & 0.47 & $0.43 * *$ & -0.04 & $0.17 * *$ & - & & & & & & & \\
\hline (e) $\log (\mathrm{MV})$ & 6.95 & 1.39 & $0.28 * *$ & $0.41 * *$ & -0.02 & -0.02 & - & & & & & & \\
\hline $\begin{array}{l}\text { (f) Market-to- } \\
\text { book ratio }\end{array}$ & 2.71 & 3.58 & $0.27 * *$ & $-0.15^{*}$ & 0.05 & 0.05 & $0.20 * *$ & - & & & & & \\
\hline $\begin{array}{l}\text { (g) Dividend } \\
\text { yield }\end{array}$ & 2.52 & 2.90 & -0.02 & $-0.12^{*}$ & -0.02 & $0.24 * *$ & $-0.18 * *$ & $-0.15^{*}$ & - & & & & \\
\hline (h) PDI & 73.10 & 15.60 & -0.02 & $-0.21 * *$ & $0.45 * *$ & $0.17 * *$ & $-0.18 * *$ & 0.01 & 0.05 & - & & & \\
\hline (i) IDV & 29.83 & 14.75 & $0.28 * *$ & $-0.44 * *$ & $-0.35 * *$ & $0.35 * *$ & 0.04 & $0.18 * *$ & 0.08 & -0.09 & - & & \\
\hline (j) MAS & 50.82 & 7.55 & $0.22 * *$ & $-0.23 * *$ & $-0.35^{* *}$ & $0.33 * *$ & 0.08 & $0.13 *$ & 0.10 & $0.14 *$ & $0.67 * *$ & - & \\
\hline (k) UAI & 46.30 & 21.65 & $-0.40 * *$ & $-0.21 * *$ & $-0.39 * *$ & $-0.64 * *$ & -0.06 & -0.03 & -0.06 & $-0.44 * *$ & -0.07 & $-0.42 * *$ & - \\
\hline
\end{tabular}

$N=271$ observations

$* p<0.05, * * p<0.01$

Pakistan (11), Philippines (14), Singapore (30), South Africa (19), South Korea (14), Taiwan (28), Thailand (13), and Turkey (15).

The data from CLSA and Hofstede's cultural dimensions were used to test the four hypotheses developed in "Theoretical foundation" section. Table 2 presents the means, standard deviations, and correlation coefficients among the variables.

\section{Results}

Table 2 presents the correlation results among the variables. There were significant correlations between the $\mathrm{CG}$ scores and the control variables. CG scores were significantly and positively correlated with the five control variables, including Log(GDP per capita) with $r=0.27$, GDP growth rate with $r=0.15$, common-law dummy with $r=0.43, \log (\mathrm{MV})$ with $r=0.28$, and market-to-book ratio with $r=0.27$. These results justified our consideration of those control variables in this analysis.

Table 3 shows the results of the multiple regression analysis. In Model 1, all six control variables were entered into the model. $\log$ (GDP per capita), common-law dummy, Log(Market Value), and market-to-book ratio were found to be statistically significant. Model 1 could predict $37 \%$ of the total variance in the CG score, and the slopes for the four variables in the model were all positive, which is consistent with our earlier discussion. The four cultural dimensions were entered into Model 2, and were also found to be significant. PDI, IDV, MAS, and UAI were able to predict $29 \%$ of the total variance in the $\mathrm{CG}$ scores. Model 2 was statistically significant at $1 \%$, indicating that cultural dimensions could significantly explain the difference in CG practices among firms.

The six control variables and the four cultural dimensions were entered into Model 3, and they were able to predict $45 \%$ of the total variance in the CG scores. The slopes for $\log$ (GDP per capita), common-law dummy, market-to-book ratio, and IDV were significantly positive, whereas those for MAS and UAI were significantly negative. Finally, the backward elimination method was applied, with the statistical significance level set at $10 \%$, for the explanatory variables in Model 3 to generate the final model, Model 4. In Model 4, the six variables, including Log(GDP per capita), common-law dummy, market-to-book ratio, IDV, MAS, and UAI, were able to predict $45 \%$ of the total variance in the CG score. The slopes for $\log (\mathrm{GDP}$ per capita), common-law dummy, market-to-book ratio, and IDV were significantly positive, whereas those for MAS and UAI were significantly negative.

\section{Discussion}

The results of this study provide empirical evidence to support the hypotheses that high IDV, low UAI, and low MAS cultures have higher CG scores. However, the empirical data did not show a significant relationship 
Table 3 Regression analysis results for corporate governance score with explanatory variables of macroeconomic variables, firm-specific variables and Hofstede's cultural dimensions

Note: Standardized regression coefficients (betas) are reported in this table

${ }^{\text {a }}$ Model 4 is the result from the backward elimination method with the statistical significance level set at $10 \%$ for the explanatory variables in Model 3

$* p<0.05, * * p<0.01$

\begin{tabular}{|c|c|c|c|c|}
\hline \multirow[t]{2}{*}{ Variables } & \multicolumn{4}{|c|}{ Dependent variable: CG Score } \\
\hline & Model 1 & Model 2 & Model 3 & Model $4^{\mathrm{a}}$ \\
\hline \multicolumn{5}{|l|}{ Control variables } \\
\hline Log(GDP per capita) & $0.28 * *$ & & $0.40 * *$ & $0.43 * *$ \\
\hline GDP growth rate & -0.01 & & 0.01 & \\
\hline Common-law dummy & $0.44 * *$ & & $0.19 * *$ & $0.18^{* *}$ \\
\hline Log(Market Value) & $0.12^{*}$ & & 0.05 & \\
\hline Market-to-book ratio & $0.26 * *$ & & $0.24 * *$ & $0.26 * *$ \\
\hline Dividend yield & -0.03 & & -0.01 & \\
\hline \multicolumn{5}{|l|}{ Independent variables } \\
\hline Power distance index (PDI) & & $-0.20^{* *}$ & 0.00 & \\
\hline Individualism (IDV) & & $0.40 * *$ & $0.46 * *$ & $0.47 * *$ \\
\hline Masculinity (MAS) & & $-0.27 * *$ & $-0.19^{*}$ & $-0.19^{*}$ \\
\hline Uncertainty avoidance index (UAI) & & $-0.57 * *$ & $-0.23^{*}$ & $-0.23 * *$ \\
\hline$R^{2}$ & 0.37 & 0.29 & 0.45 & 0.45 \\
\hline Adjusted $R^{2}$ & 0.35 & 0.28 & 0.43 & 0.44 \\
\hline df (regression, residual) & $(6,264)$ & $(4,266)$ & $(10,260)$ & $(6,264)$ \\
\hline$F$ & $25.47 * *$ & $26.79 * *$ & $21.41 * *$ & $35.92 * *$ \\
\hline
\end{tabular}

between PDI cultures and CG scores after the consideration of the control variables and other cultural dimensions. IDV, MAS, UAI, and three control variables ( $\log ($ GDP per capita), common-law dummy, and market-to-book ratio) were able to predict $45 \%$ of the total variance in the CG scores. The following sections will discuss the significant predictive power of IDV, MAS, and UAI for CG scores, based on the concept of ethical sensitivity. Moreover, one section will discuss the insignificance of PDI on CG scores, given the other control variables.

\section{IDV Cultures and CG Scores}

The empirical result showed that IDV significantly and positively predicted CG scores, and this result is consistent with Hypothesis 2. Armstrong's (1996) findings suggested that IDV and ethical sensitivity were positively correlated, with leaders and employees in IDV cultures being more aware and sensitive to ethical standards. Chan and Cheung (2008) mentioned that investors in high IDV cultures emphasized individual view and fair treatment from firms. The stakeholders in high IDV countries will closely monitor, and are very sensitive to, whether the firms that they invested in are protecting their rights and benefits by strictly following CG. Hofstede and Hofstede (2005) described people in high IDV cultures as preferring reward allocation based on equity for all and believing that rights are supposed to be the same for all. Ensuring that firms follow CG practices is one way to achieve the above preferences and beliefs. The ethical sensitivity of people in high IDV cultures actually pressures corporate management to follow CG practices. Husted's (2000) study also showed that an increase in economic development was related to fewer cases of software piracy across countries, and that high IDV score and ethical sensitivity helped lower the number of unethical acts. Similarly, high IDV scores, ethical sensitivity, and CG scores are beneficial to the overall economic development of countries.

\section{MAS Cultures and CG Scores}

The results of this study also showed that MAS significantly and negatively predicted CG scores. Consistent with Hypothesis 3, the CG scores were high in low MAS cultures. In other words, high MAS cultures were found to have lower quality of CG. As discussed above, Blodgett et al. (2001) found that people in high MAS societies showed less ethical sensitivity. Lu et al. (1999) found that people in high MAS cultures were less likely to be influenced by formal codes of ethics and less likely to adopt deontological ethics (described as duty- or obligationbased ethics). This is because individuals in these cultures are very concerned with personal achievement and material success, and often have a low sense of responsibility; thus, they are likely to value their own interests more highly than those of others (Hofstede 2001). Generally speaking, MAS cultures are the opposite of feminine cultures, in which people are described as compassionate, understanding, and empathetic toward others, and as having stronger ethical sensitivity (Nadler 2002). 
Good CG practice means that the internal corporate management provides better accountability to external stakeholders and offers better protection of their interests. Higher accountability and more transparency to external stakeholders give the internal corporate management less opportunity to gain personal benefits from the operation of the firm. As people in high MAS cultures value personal achievement and material success, managers in such cultures are less likely to follow good CG practice to protect the interests of external stakeholders. Rather, managers in high MAS cultures are more likely to have their own set of corporate management practices so as to achieve their personal benefits. Studies have found the incidence of corruption to be higher in high MAS cultures, and that people from these cultures are likely to overlook ethically questionable business practices (Cohen et al. 1992; Getz and Volkamam 2001; Moon and Franke 2000). The characteristics of people in high MAS cultures lead to a low degree of ethical sensitivity; thus, it is difficult for firms in such cultures to achieve high CG scores.

\section{UAI Cultures and CG Scores}

UAI was found to be significantly and negatively related to CG scores across cultures, and this result is consistent with Hypothesis 4. As noted, good CG practice is a set of guidelines, not a set of formal laws and regulations that business practitioners must follow. These CG guidelines are suggestions for the internal management on how to run a company with better accountability to external stakeholders. Existing literature (Vitell et al. 1993; Husted 2000; Weaver 2001) indicated that individuals in high UAI cultures were highly compliant with formal rules and laws guiding their ethical behaviors and they avoided deviation. However, when there is no formal law or regulation governing a business decision, a high UAI manager is less likely to recognize the ethical issue in the business decision. Schepers (2006) also noted that higher UAI cultures were associated with higher ethical perception and reasoning. However, the study further explained that people in high UAI cultures were ethnocentric and loyal to the demands of in-group members. Thus, these people may only be sensitive to ethics set by themselves or in-group members, but it would be difficult for them to follow a set of ethical guidelines, which are developed for the interests of out-group members. The guidelines for good CG practice can be viewed as a set of requirements or constraints for the internal management to provide better accountability to external stakeholders. However, the internal corporate management in high UAI cultures may not view the external stakeholders as in-group members. Thus, they may not be ethically sensitive to the guidelines for good CG practices. In other words, high UAI cultures have high ethical sensitivity to formal laws and regulations; however, these ethical rules are seen as more applicable to the ingroup members. On the other hand, as good CG practice is a set of informal guidelines (not legally binding rules and regulations), and are developed for the interests of external stakeholders (out-group members), it explains the low CG scores found in high UAI cultures.

Additionally, uncertainty avoidance is a problem-solving method that is a superficial and short-term strategy (Schepers 2006). People using this strategy are merely trying to control and reduce future uncertainty through an immediate (but perhaps not the best) solution to current problems. Implementing any new policy to improve CG practice will induce uncertainty of future outcomes to the management team; furthermore, it takes some time for them to realize the benefits. People from high UAI cultures may feel uncomfortable adopting any new management practices when their 'own' ethical codes, which are beneficial to in-group members, have been applied for so long.

\section{PDI Cultures and CG Scores}

PDI was statistically significant in explaining CG scores in Model 2, along with the other three cultural dimensions of IDV, MAS, and UAI. However, when control variables were incorporated in Models 3 and 4, PDI became statistically insignificant. We interpreted this change as a result of the significant negative relationship between PDI and Log(GDP per capita), which captured the explanatory power of PDI on CG score and made PDI statistically insignificant. To confirm this interpretation, we removed the variable of $\log$ (GDP per capital) from Models 3 and 4 and found that PDI became negatively significant again. Furthermore, PDI remained statistically insignificant if we removed any other control variables from Models 3 and 4.

\section{Conclusions and Limitations}

The results showed that IDV, MAS, UAI, and the three control variables, including Log(GDP per capita), common-law dummy, and market-to-book ratio, had significant explanatory power in predicting CG scores for firms across different countries. Previous studies focused on economic factors and the legal systems to explain CG development; however, this study demonstrated that cultural factors also play an important role after economic factors and legal factors were controlled. As the ethical sensitivity of individuals is a more fundamental factor determining the effectiveness of the implementation of any legal system, and different cultures have different ethical values, it is important for researchers to continue to investigate the development of $\mathrm{CG}$ practices from the cultural perspective. 
Generally speaking, people from different cultures will have different levels of ethical sensitivity and their levels of ethical sensitivity are influenced by the values and beliefs that are socialized by people in their cultures. In fact, we should try to understand others who have different levels of ethical sensitivity than us because they have been brought up in such a way. When discussing CG, continuous patience, education and negotiation are needed to show people who hold low ethical sensitivity to CG that inappropriate ethical sensitivity and perception in doing businesses is harmful to society. At the same time, in cultures where people have lower ethical sensitivity to CG, closer observation may be needed to ensure that they are following the appropriate ethical guidelines.

One important limitation of this research was a consequence of our CG dataset. There were only 271 observations from 12 countries and regions in this study. More company observations from different regions would give a more comprehensive analysis of how the firm-specific factors determine the differences in CG practice, after the factors of economic and regulatory environment are controlled. Moreover, the company observations were from emerging financial markets. The empirical results would be more interesting if the company observations from the developed financial markets were also included. Another limitation of this study was the age of the CG data, which was obtained from CLSA (2001), as more recent CG data were not available. First, as the more recent reports of 'CG Watch' from CLSA only provided the overall CG scores for individual countries (not for individual firms), the latest firm-level CG data were not available for our investigation. Second, recent CG studies by CLSA covered only limited financial markets. For example, CLSA (2001) provided the survey data for individual firms in 25 countries/regions; however, CLSA (2010) only provided the overall market CG scores for 11 countries/regions. South Africa and Pakistan, included in our analysis, were not covered in CLSA (2010). Hence, we could not obtain more recent CG data to analyze the variation in CG practices for the 271 samples in this study, over the past 10 years. To understand if there were any major changes in the CG practice across countries over the past 10 years, we present two summaries for CG scores from CLSA (2001) and CLSA (2010). Table 4 presents the country macro CG score for each country in our analysis, which was calculated from five macro determinants or market factors of CG practice for each country; Table 5 presents the average firm-level CG score for each country in our analysis, which was calculated from the average of CG scores for firms covered by the CLSA survey. As CLSA had changed both the survey questions and the CG score calculation method over the last 10 years, it may not be appropriate to make any direct comparison between the absolute CG scores from the two
Table 4 Country Macro CG Score and Market CG Score in 2001 and 2010

\begin{tabular}{lll}
\hline & $\begin{array}{l}\text { Country macro CG } \\
\text { score in 2001 }\end{array}$ & $\begin{array}{l}\text { Market CG } \\
\text { score in 2010 }\end{array}$ \\
\hline Singapore & 7.4 & 67 \\
Hong Kong & 6.8 & 65 \\
South Africa & 5.5 & $\mathrm{n} / \mathrm{a}$ \\
India & 5.4 & 49 \\
Taiwan & 5.3 & 55 \\
South Korea & 3.8 & 45 \\
Thailand & 3.7 & 55 \\
Malaysia & 3.7 & 52 \\
Philippines & 3.3 & 37 \\
Indonesia & 3.2 & 40 \\
Pakistan & 3.1 & $\mathrm{n} / \mathrm{a}$ \\
\hline
\end{tabular}

Country macro CG score in 2001 is obtained from Figure 25: Country Macro Ranking in page 37 of CLSA (2001). The country macro CG score in 2001 is the weighted average of five macro determinants of CG, including: (i) Rules and regulations (10\%), (ii) Enforcement and regulation (30\%), (iii) Political/regulatory environment (20\%), (iv) Adoption of IGAAP (20\%), and (v) Institutional mechanism and CG culture (20\%). The full score is 10

Market CG score in 2010 is obtained from Figure 3: Market Category Scores in page 7 of CLSA (2010). The market CG score in 2010 is the simple average of five macro determinants of CG, including: (i) CG rules and practice, (ii) Enforcement, (iii) Political and regulatory, (iv) IGAAP, and (v) CG culture. The full score is 100

The country macro CG scores are presented in a descending order of country macro CG scores in 2001

CLSA (2010) does not provide any CG score for South Africa and Pakistan

reports. Instead, we compared the country rankings of CG performance in the two periods. Although there were some differences in the ranking in the two periods-for example, Thailand demonstrated an improvement in CG practiceon the whole, we can see that the rankings for countries' macro CG scores and for firm-level overall CG scores were quite stable. Singapore and Hong Kong maintained high CG performance over the past 10 years, while Indonesia and Philippines maintained low CG performance over the past 10 years. Hence, our empirical findings should still be valid for the latest market situation.

In terms of future studies, a possible research direction is to investigate how the ownership structure of a firm affects CG practice. La Porta et al. (1999) provided a detailed survey about ownership structures in different markets. Corporations in the United States and the United Kingdom usually have a dispersed ownership structure without a controlling shareholder. Corporations in France, Germany, and Italy often have a pyramid ownership structure in which the controlling shareholder indirectly controls the corporation through his/her ownership of one or more corporations. Moreover, corporations in Hong 
Table 5 Firm-level overall average CG scores in 2001 and 2010

\begin{tabular}{lll}
\hline & $\begin{array}{l}\text { Average CG } \\
\text { score in 2001 }\end{array}$ & $\begin{array}{l}\text { Average CG } \\
\text { score in 2010 }\end{array}$ \\
\hline South Africa & 69.3 & $\mathrm{n} / \mathrm{a}$ \\
Singapore & 64.5 & 57.8 \\
Hong Kong & 62.9 & 56.0 \\
Malaysia & 56.6 & 54.5 \\
India & 55.6 & 53.0 \\
Thailand & 55.1 & 61.7 \\
Taiwan & 54.6 & 49.0 \\
South Korea & 47.1 & 52.4 \\
Philippines & 43.9 & 53.9 \\
Indonesia & 37.3 & 41.3 \\
Pakistan & 33.9 & $\mathrm{n} / \mathrm{a}$ \\
\hline
\end{tabular}

Average CG score in 2001 is obtained from Appendix 2: CG Country Average in page 206 of CLSA (2001). It is the simple average of CG scores for sample firms covered by the CLSA survey in CLSA (2001). The full score is 100

Average CG score in 2010 is obtained from Figure 25: Overall CG scores and by Categories for Companies in page 34 of CLSA (2010). It is the simple average of CG scores for sample firms covered by the CLSA survey in CLSA (2010). The full score is 100

The Average CG scores are presented in a descending order of the Average CG scores in 2001

CLSA (2010) does not provide any CG score for South Africa and Pakistan

Kong and Mexico usually have a family ownership structure with a controlling shareholder. Anderson and Reeb (2003) found that firms with a founding-family ownership structure demonstrated significantly better performance and argued that the family ownership structure of public firms reduced agency problems under a well-regulated and transparent market. This result leads us to consider the potential relationship between CG practice and ownership structure. Furthermore, Enriques and Volpin (2007) studied the corporate law reforms in France, Germany, and Italy to enhance CG practice for their firms, and these countries usually have pyramid ownership structures. Hence, the ownership structure of firms may be another important determinant for the evolution of CG practice in a country. It is worthwhile investigating this firm-specific variable, the ownership structure, to explain CG practice across firms.

Furthermore, this study demonstrated the significant impact of cultural dimensions on CG practice. Future researchers may investigate how the national culture of a foreign manager affects the CG practice of a domestic firm, and also investigate the optimal match between the national culture of a foreign manager and the national culture of a domestic firm for enhancing CG practice.
Open Access This article is distributed under the terms of the Creative Commons Attribution Noncommercial License which permits any noncommercial use, distribution, and reproduction in any medium, provided the original author(s) and source are credited.

\section{References}

Anderson, R. C., \& Reeb, D. M. (2003). Founding family ownership and firm performance: Evidence from the S\&P 500. Journal of Finance, 58(3), 1301-1328.

Armstrong, R. W. (1996). The relationship between culture and perception of ethical problems in international marketing. Journal of Business Ethics, 15, 1199-1208.

Black, B. S., Jang, H., \& Kim, W. (2006a). Does corporate governance predict firms' market values? Evidence from Korea. The Journal of Law, Economics \& Organization, 22(2), $366-412$.

Black, B. S., Jang, H., \& Kim, W. (2006b). Predicting firms' corporate governance choices: Evidence from Korea. Journal of Corporate Finance, 12(3), 660-691.

Blodgett, J. G., Lu, L. C., Rose, G. M., \& Vitell, S. J. (2001). Ethical sensitivity to stakeholder interests: A cross-cultural comparison. Journal of Academy of Marketing Science, 29(2), 190-202.

Bonn, I., \& Fisher, J. (2005). Corporate governance and business ethics: Insights from the strategic planning experience. Corporate Governance: An International Review, 13(6), 730-738.

Chan, A. W. H., \& Cheung, H. Y. (2008). Common cultural relationships in corporate governance across developed and emerging financial markets. Applied Psychology: An International Review, 57(2), 225-245.

Chen, A. Y. S., Sawyers, R. B., \& Williams, P. F. (1997). Reinforcing ethical decision making through corporate culture. Journal of Business Ethics, 16, 855-865.

Cohen, J. R., Pant, L. W., \& Sharp, D. J. (1992). Cultural and socioeconomic constraints on international codes of ethics: Lesson from accounting. Journal of Business Ethics, 11, 687-700.

Cohen, J. R., Pant, L. W., \& Sharp, D. J. (1996). A methodological note on cross-cultural accounting ethics research. The International Journal of Accounting, 31(1), 55-66.

Credit Lyonnais Securities Asia (CLSA). (2001). Saints and sinners: Who's got religion. CG Watch.

Credit Lyonnais Securities Asia (CLSA). (2010). Stray not into perdition-Asia's CG momentum slows. CG Watch, ACGA in collaboration with the Asian Corporate Governance Association.

Doidge, C., Karolyi, G. A., \& Stulz, R. M. (2007). Why do countries matter so much for corporate governance? Journal of Financial Economics, 86(1), 1-39.

Durnev, A., \& Kim, E. H. (2005). To steal or not to steal: Firm attributes, legal environment, and valuation. Journal of Finance, 60, 1461-1493.

Easterbrook, F. H. (1984). Two agency-cost explanations of dividends. The American Economic Review, 74(4), 650-659.

Enriques, L., \& Volpin, P. (2007). Corporate governance reforms in continental Europe. Journal of Economic Perspectives, 21(1), $117-140$.

Felo, A. J. (2001). Ethics programs, board involvement, and potential conflicts of interest in corporate governance. Journal of Business Ethics, 32, 205-218.

Fernando, M., \& Chowdhury, R. M. M. I. (2010). The relationship between spiritual well-being and ethical orientations in decision making: An empirical study with business executives in Australia. Journal of Business Ethics, 95, 211-225. 
Franke, G. R., \& Nadler, S. S. (2008). Culture, economic development, and national ethical attitudes. Journal of Business Research, 61, 254-264.

Garay, U., \& González, M. (2008). Corporate governance and firm value: The case of Venezuela. Corporate Governance: An International Review, 16(3), 194-209.

Getz, K. A., \& Volkamam, R. J. (2001). Culture, perceived corruption, and economics. Business and Society, 40(1), 7-30.

Gompers, P. A., Ishii, J., \& Metrick, A. (2003). Corporate governance and equity prices. The Quarterly Journal of Economics, 118(1), $107-155$.

Hebert, P., Meslin, E. M., Dunn, E. V., Byren, N., \& Reid, S. R. (1990). Evaluating ethical sensitivity in medical students: Using vignettes as an instrument. Journal of Medical Ethics, 16, 141-145.

Ho, Y. H., \& Lin, C. Y. (2008). Cultural values and cognitive moral development of accounting ethics: A cross-cultural study. Social Behavior and Personality, 36(7), 883-892.

Hofstede, G. (1984). Culture's consequences. London: Sage Publications.

Hofstede, G. (2001). Culture's consequences: Comparing values, behaviors, institutions, and organizations across nations. Beverly Hills, CA: Sage Publication.

Hofstede, G., \& Bond, M. H. (1988). The Confucius connection: From cultural roots to economic growth. Organizational Dynamics, 16(1), 5-21.

Hofstede, G., \& Hofstede, G. J. (2005). Cultures and organizations: Software of the mind. NY: McGraw Hill.

Husted, B. W. (2000). The impact of national culture on software piracy. Journal of Business Ethics, 26, 197-2000.

Husted, B., \& Allen, D. (2008). Toward a model of cross-cultural business ethics: The impact of individualism and collectivism on the ethical decision-making process. Journal of Business Ethics, 82, 293-305.

Hwang, A., Francesco, A. M., \& Kessler, E. (2003). The relationship between individualism-collectivism, face, and feedback and learning processes in Hong Kong, Singapore, and the United States. Journal of Cross-Cultural Psychology, 34(1), 72-91.

International Management Development Institute (IMD). (2001). The world competitiveness yearbook 2001. Switzerland: Lausanne.

Jackson, T. (2001). Cultural values and management ethics: A 10-nation study. Human Relations, 54(10), 1267-1302.

Jensen, M. C. (1986). Agency cost of free cash flow, corporate finance, and takeovers. American Economic Review Papers and Proceedings, 76, 323-329.

Jensen, M. C., \& Meckling, W. (1976). Theory of the firm: Managerial behaviour, agency costs and ownership structure. Journal of Financial Economics, 3, 305-360.

Khanna, T., Kogan, J., \& Palepu, K. (2006). Globalization and similarities in corporate governance: A cross-country analysis. The Review of Economics and Statistics, 88(1), 69-90.

Klapper, L. F., \& Love, I. (2004). Corporate governance, investor protection, and performance in emerging markets. Journal of Corporate Finance, 10, 703-728.

La Porta, R., Lopez-de-Silanes, F., \& Shleifer, A. (1999). Corporate ownership around the world. Journal of Finance, 54(2), 471-517.

La Porta, R., Lopez-de-Silanes, F., Shleifer, A., \& Vishny, R. (1998). Law and finance. Journal of Political Economy, 106(6), 1113-1155.

Lending, D., \& S. A. Slaughter. (1999). Understanding differences in ethical beliefs and behaviors toward software copying: The effects of organization culture. Paper presented at Special Interest Group on Computer Personnel Research Annual Conference, New Orleans, Louisiana.

Lu, L. C., Rose, G. M., \& Blodgett, J. G. (1999). The effects of cultural dimensions on ethical decision making in marketing: An exploratory study. Journal of Business Ethics, 18, 91-105.
Mintz, S. M. (2006). Loeb's contribution to accounting ethics education and research. Research on Professional Responsibility and Ethics in Accounting, 11, 31-46.

Moon, Y. S., \& Franke, G. R. (2000). Cultural influences on agency practitioners' ethical perceptions: A comparison of Korea and the U.S. Journal of Advertising, 29(1), 51-65.

Nadler, S. S. (2002). Business implications of national culture, religiosity, and ethical sensitivity: A multi-country investigation. Unpublished doctoral dissertation, The University of Alabama, Alabama.

Nicolò, G. D., Laeven, L., \& Ueda, K. (2008). Corporate governance quality: Trends and real effects. Journal of Financial Intermediation, 17(2), 198-228.

Organization for Economic Cooperation, Development (OECD). (2004). OECD principles of corporate governance. France: OECD Publications Service.

Orlitzky, M., \& Swanson, D. L. (2010). Do executives who prefer exorbitant salaries downplay ethics? Decision Line, 3, 11-14.

Patterson, D. M. (2001). Causal effects of regulatory, organizational and personal factors on ethical sensitivity. Journal of Business Ethics, 30, 123-159.

Rawwas, M. (2001). Culture, personality and morality: A typology of international consumers' ethical beliefs. International Marketing Review, 18(2), 188-209.

Rossouw, G. J. (2005). Business ethics and corporate goverance in Africa. Business and Society, 44(1), 94-106.

Rozeff, M. (1982). Growth, beta and agency costs as determinants of dividend payout ratios. Journal of Financial Research, 5, 249-259.

Schepers, D. H. (2006). Three proposed perspectives of attitude toward business' ethical responsibilities and their implications for cultural comparison. Business and Society Review, 111(1), 15-36.

Shaub, M. L. (1989). An empirical examination of the determinants of auditor's ethical sensitivity. Unpublished doctoral dissertation, Texas Technological University, Lubbock, TX.

Shaub, M. K., Finn, D. W., \& Munter, P. (1993). The effects of auditors' ethical orientation on commitment and ethical sensitivity. Behavioral Research in Accounting, 5, 145-169.

Simga-Mugan, C., Daly, B. A., Onkal, D., \& Kavut, L. (2005). The influence of nationality and gender on ethical sensitivity: An application of the issue-contingent model. Journal of Business Ethics, 57, 139-159.

Smith, P. B., Dugan, S., \& Trompenaars, F. (1996). National culture and the values of organizational employees: A dimensional analysis across 43 nations. Journal of Cross-Cultural Psychology, 27, 231-264.

Smith, A., \& Hume, E. C. (2005). Linking culture and ethics: A comparison of accountants' ethical belief systems in the individualism/collectivism and power distance contexts. Journal of Business Ethics, 62, 209-220.

Thomas, C. W. (2004). An inventory of support materials for teaching ethics in the post-enron era. Issues in Accounting Education, 19(1), 27-52.

Triandis, H. C. (1995). Individualism and collectivism. Boulder, CO: Westview.

Triandis, H. C. (1996). The psychological measurement of cultural syndromes. American Psychologist, 51, 407-415.

Triandis, H. C., Chen, X. P., \& Chan, D. K. S. (1998). Scenarios for the measurement of collectivism and individualism. Journal of Cross-Cultural Psychology, 29, 275-289.

Vitell, S. C., \& Festervand, T. A. (1987). Business ethics: Conflicts, practices and beliefs of industrial executives. Journal of Business Ethics, 6, 111-122.

Vitell, S. J., Nwachukwu, S. L., \& Barnes, J. H. (1993). The effects of culture on ethical decision making: An application of Hofstede's typology. Journal of Business Ethics, 12, 753-760. 
Weaver, G. R. (2001). Ethics programs in global business: Culture's role in managing ethics. Journal of Business Ethics, 30(1), 3-15.

Webley, S., \& Werner, A. (2008). Corporate codes of ethics: Necessary but not sufficient. Business Ethics: A European Review, 17(4), 405-415.

World Bank. (2006). World development indicators 2006. Washington, DC: International Bank for Reconstruction and Development/The World Bank. 